\title{
Emotional Intelligence and Stress Coping Strategies Among Students of Physical Education and Sport Study Programs
}

\author{
Romualdas Malinauskas, Tomas Saulius, Giedrius Kaufmanas \\ Lithuanian Sports University, Kaunas, Lithuania
}

\begin{abstract}
Background. Studies of various scholars confirm the relation between the application of stress coping strategies and emotional intelligence, but there is a lack of research about the relationship between individual coping strategies and emotional intelligence levels among the first- and the fourth-year students. The aim of the research was to reveal peculiarities of emotional intelligence and stress coping strategies of undergraduate students of physical education and sport study programs.

Methods. The Shutte Self-Assessment Questionnaire was used to measure the level of emotional intelligence of the participants (Schutte \& Malouff, 1999). The questionnaire composed by Grakauskas and Valickas (2006) was used to identify the stress coping strategies. It consists of four factors: social support factor, problem-solving factor, emotional discharge factor and avoidance factor. The research was based on the following ethical principles: confidentiality, anonymity, impartiality and privacy. The first- and the fourth-year students of the Lithuanian Sports University and Lithuanian University of Educational Sciences, Physical Education and Sports Programs were surveyed. The research sample consisted of 123 participants. Male participants comprised $66.7 \%$ of the sample, and the female participants comprised $33.3 \%$. of the sample. The first-year undergraduates made up $57.7 \%$ of the sample, and the fourth-year undergraduates made up $42.3 \%$ of the sample.

Results. Analyzing the data on the stress coping strategies according to the participants studying experience, it was found that the fourth-year students used the social support strategy more frequently in comparison with the firstyear students. In addition, the fourth-year students applied emotional discharge and avoidance strategies more often than the first-year students. Comparing stress coping strategies and emotional intelligence according to the gender of participants, no statistically significant differences were found. There was a statistically significant relationship between the stress coping strategy and the ability to evaluate and express one's emotions.

Conclusions. Comparing emotional intelligence of the first- and the fourth-year students of physical education and sports study programs, no statistically significant differences were found. Comparison of stress coping strategies applied by the first- and the fourth-year students of physical education and sports degree programs revealed that the fourth-year students tended to use social support, emotional discharge and avoidance strategies more frequently than the first-year students. Comparison of stress coping strategies and emotional intelligence according to gender did not show any statistically significant differences. However, there was a statistically significant relationship between stress coping strategies and emotional intelligence, though it was a weak, but significant difference between emotional intelligence components such as the ability to express and manage emotions and problem-solving focused stress coping strategy.
\end{abstract}

Keywords: stress, stress management strategies, emotional intelligence.

\section{INTRODUCTION}

$\mathrm{R}$ ecently, scientific interest into the problems of stress and coping with it has been decreasing. Stress is usually experienced at work or in an educational institution, and at home.
Stress at home can be eliminated by choosing to rest or refocusing tension to another object. However, it is difficult to reduce the stress at school or at work because any individual is dependent on his or her 
co-workers or peers, the social environment, and the current situation (Brougham, Zail, Mendoza, \& Miller, 2009). The stress experienced by an individual does not necessarily motivate them to implement new ideas, to purse their goals, to improve themselves in various fields. Stress can also lead to negative experiences, doubts about one's abilities and worth. It should be noted, however, that recent research on the effects of stress on people has focused more on stress management methods used by people of all ages, occupations and social groups, not so much on the intensity of stress itself and its impact on human health. According to one of the most widely used definitions of the concept at present, stress coping is an everchanging behavioral, cognitive, and emotional effort to deal with specific internal and/or external demands that complicate or exceed a person's capabilities (Lazarus, 2006). There is an increase in the number of scientific studies into the relationship between individuals' choice of coping strategies and various mental phenomena - personality traits (Connor-Smith \& Flachsbart, 2007), temperament (Chaplain, 2009), emotional intelligence (Por, Barriball, Fitzpatrick, \& Roberts, 2011).

Scientific research of stress in learning activities, based on the general theory of stress and the characteristics of the occupational stress experienced, usually focuses on the informational dimension of occupational stress, which in the scientific literature is referred to as "informational stress" (Hasnulin et al., 2014). The information component of stress, being a derivative variable, pervades all events in an individual's life and exerts a profound psychological and physiological influence on them. Information stress is especially conspicuous in students' learning activities, which are pervaded with the large amounts of information acquired from teaching, scientific, and other types of sources, coming from the external natural and social environment.

According to Glozah (2013), informational stress is a psychological state of being overloaded with information, when the subject responsible for the performance experiences a time deficit and is unable to make the right decision on time. As Postek, Ledzińska, and Czarkowski (2010) point out, information stress is the response of an individual's body to the large amounts of information from different sources when the volume of information and intensity of the response tend to grow. Hasnulin et al. (2014) believe that the source of this kind of stress is both information that comes from the external environment and becomes an actual or potential threat to make a negative impact on an individual, as well as information that comes from the "inside" of an individual, that is, mental images of previous adverse events and their consequences. At work and during the learning process informational stress is usually being induced not only by negative past events that are stored in the human memory, but also by present and future events that have some significance in the individual's subjective world and force them to activate internal resources (Hasnulin et al., 2014). Therefore, it can be reasonably argued that informational stress that occurs during students' learning activities is a phenomenon which can be characterized in terms of negative effects on student's personality. In addition, some studies (e.g. Por et al., 2011) indicate that a person's response to stress also depends on their emotional intelligence.

Scientific problem. In the scientific literature, research usually deals with the relationship between stress coping or emotional intelligence with various isolated mental attributes of an individual. Therefore, although various scholars are interested in how students of sports universities chose stress coping strategies and what the links between them and emotional intelligence are (Ekici et al., 2012), it remains unclear how emotional intelligence of students of physical education and sports study programs relates to stress coping strategies they chose to apply. The search for an answer to this question underlies the scientific problem of this research. The formulation of the research question allowed us to formulate the following hypotheses of this research:

H1: the fourth-year undergraduate students have higher scores of emotional intelligence components and problem-solving oriented stress coping strategies compared to the first-year undergraduates.

H2: Girls have a higher level of ability to understand and analyze emotions, while boys have better control over emotions, and girls have higher scores of problem-solving oriented stress coping strategies than boys.

\section{METHODS}

Instruments. In the research the following questionnaires were used:

1. Shutte et al. (1998) questionnaire of emotional intelligence was used to determine the level of emotional intelligence. This methodology helps 
to assess four (Palmer, 2003) components of emotional intelligence: first, ability to evaluate and express emotions; second, ability to rely on one's emotional experience; third, ability to control emotions; and last, ability to understand and analyze emotions. The questionnaire was designed to measure the degree to which participants are able to apply, understand, identify and independently control their own emotions and those of others. This questionnaire was used to measure participants' emotional intelligence because of its simplicity.

2. A questionnaire composed by Grakauskas and Valickas (2006) was used to identify stress coping strategies, which consists of four factors: first, social support factor, which reflects stress coping strategies related to social support; second, problem-solving factor including questionnaire statements related to problemsolving strategies; third, emotional discharge factor, including statements that represent respondent's attempts to overcome a stressful situation by pouring out accumulated negative emotions and finding those who are responsible for stress; fourth, the avoidance factor including the questionnaire statements reflecting stress coping strategies associated with psychological avoidance were assigned.

The questionnaire also included a sociodemographic section that asked participants about their gender and the year of study.

Organization of the research. First and fourth year undergraduate students $(n=123)$ of physical education and sports programs of Lithuanian Sports University and Lithuanian University of Educational Sciences (now Vytautas Magnus University) were interviewed. The study was carried out in accordance with the following principles of scientific research ethics: confidentiality, anonymity, impartiality and privacy. The majority of participants were male students (66.7\%), and female students made up $33.3 \%$. First year students made up $57.7 \%$ of the sample of the current survey, and fourth year students comprised $42.3 \%$ of the participants.

Statistical analysis. IBM SPSS Statistics 22.0 software package for Windows was used to analyze the research data. The data distribution was verified to be normal. Cronbach's alpha coefficients were calculated: Cronbach's alpha for the Emotional Intelligence Questionnaire was .93, and it was .73 for the Stress Coping Strategies Questionnaire.
Mean values and standard deviations of the responses were calculated and Student's $t$ test was applied to compare the means. Significance level $p<.05$ was selected for the current analysis.

\section{RESULTS}

The level of emotional intelligence and stress coping strategies were systematized according to the gender of the participants and the study year. Attempts were made to identify the relation between the coping strategies and the components of emotional intelligence. Differences in the mean scores of the emotional intelligence and the strategies for coping with stress according to study year are presented in Table 1.

Results in Table 1 suggest that there were no statistically significant differences in the mean estimates of emotional intelligence and its components according to the year of study.

The mean $(3.44 \pm 0.61)$ of the fourth-year undergraduates' social support strategy ratings was higher than the mean of the first-year students (3.21 \pm 0.61$)$. This difference in estimates is statistically significant $(t(121)=-2.092, p<.05)$. Therefore, it can be concluded that fourth-year students prefer a social support strategy more than first-year students.

The mean $(3.38 \pm 0.57)$ of the first-year study undergraduates' emotional discharge (as a stress coping strategy) ratings was lower than the fourthyear undergraduates' ratings ( $3.61 \pm 0.57)$. Applying Student's $t$ criterion, it was found that the means of these estimates differed statistically significantly $(t(121)=-2.179, p<.05)$. Therefore, it can be concluded that the fourth-year undergraduates use emotional discharge strategy more frequently than the first-year undergraduates.

The mean of avoidance (as a stress coping strategy) application among the first-year undergraduates $(3.48 \pm 0.59)$ was lower than that among the fourth-year undergraduates $(3.63 \pm 0.51)$. Applying Student's $t$ criterion, it was found that the means of these estimates differed statistically significantly $(t(121)=-2.793, p<.05)$. Therefore, it can be concluded that in coping with stress the fourth-year students use avoidance strategy more frequently than the first-year students.

The differences in the mean estimates of emotional intelligence and stress coping strategies according to participants' gender are presented in Table 2. 
Table 1. Differences in the mean scores of the emotional intelligence and the stress coping strategies according to the year of study

\begin{tabular}{|c|c|c|c|c|c|c|c|c|}
\hline Components & $\begin{array}{l}\text { Study } \\
\text { year }\end{array}$ & $N$ & Mean & $\begin{array}{l}\text { Standard } \\
\text { Deviation }\end{array}$ & $F$ & $p$ & $t(121)$ & $p$ \\
\hline \multirow{2}{*}{$\begin{array}{l}\text { Ability to draw on one's } \\
\text { emotional experience }\end{array}$} & 1 & 71 & 3.78 & .452 & \multirow{2}{*}{.008} & \multirow{2}{*}{.929} & \multirow{2}{*}{-.070} & \multirow{2}{*}{.944} \\
\hline & 4 & 52 & 3.78 & .434 & & & & \\
\hline \multirow{2}{*}{$\begin{array}{l}\text { Ability to understand and } \\
\text { analyze emotions }\end{array}$} & 1 & 71 & 3.89 & .523 & \multirow{2}{*}{.094} & \multirow{2}{*}{.760} & \multirow{2}{*}{.802} & \multirow{2}{*}{.424} \\
\hline & 4 & 52 & 3.81 & .524 & & & & \\
\hline \multirow{2}{*}{$\begin{array}{l}\text { Ability to evaluate and } \\
\text { express emotions }\end{array}$} & 1 & 71 & 3.62 & .556 & \multirow{2}{*}{.095} & \multirow{2}{*}{.758} & \multirow{2}{*}{-.456} & \multirow{2}{*}{.649} \\
\hline & 4 & 52 & 3.67 & .575 & & & & \\
\hline \multirow{2}{*}{$\begin{array}{l}\text { Ability to manage } \\
\text { emotions }\end{array}$} & 1 & 71 & 3.31 & .606 & \multirow{2}{*}{.193} & \multirow{2}{*}{.661} & \multirow{2}{*}{.228} & \multirow{2}{*}{.820} \\
\hline & 4 & 52 & 3.28 & .667 & & & & \\
\hline \multirow{2}{*}{ Social support } & 1 & 71 & 3.21 & .591 & \multirow{2}{*}{.147} & \multirow{2}{*}{.702} & \multirow{2}{*}{-2.092} & \multirow{2}{*}{$.039 *$} \\
\hline & 4 & 52 & 3.44 & .614 & & & & \\
\hline \multirow{2}{*}{ Problem solving } & 1 & 71 & 3.46 & .519 & \multirow{2}{*}{.128} & \multirow{2}{*}{.721} & \multirow{2}{*}{-1.250} & \multirow{2}{*}{.214} \\
\hline & 4 & 52 & 3.57 & .483 & & & & \\
\hline \multirow{2}{*}{ Emotional discharge } & 1 & 71 & 3.38 & .566 & \multirow{2}{*}{.003} & \multirow{2}{*}{.957} & \multirow{2}{*}{-2.179} & \multirow{2}{*}{$.031 *$} \\
\hline & 4 & 52 & 3.61 & .573 & & & & \\
\hline Avoidance & 1 & 71 & 3.37 & .494 & 094 & 760 & 2703 & $006 *$ \\
\hline Rvoricante & 4 & 52 & 3.63 & .505 & .074 & .100 & -2.170 & .000 \\
\hline Fmotional Intelligence & 1 & 71 & 3.60 & .397 & 002 & 056 & 121 & 004 \\
\hline 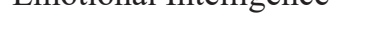 & 4 & 52 & 3.59 & .386 & .000 & ( > > & .121 & ד \\
\hline
\end{tabular}

Note. $* p<.05$.

Table 2. Differences between the means of the estimates of emotional intelligence and stress coping strategies according to gender of participants

\begin{tabular}{|c|c|c|c|c|c|c|c|c|}
\hline Components & Gender & $N$ & Mean & $\begin{array}{l}\text { Standard } \\
\text { Deviation }\end{array}$ & $F$ & $p$ & $t(121)$ & $p$ \\
\hline \multirow{2}{*}{$\begin{array}{l}\text { Ability to draw on one's } \\
\text { emotional experience }\end{array}$} & Female & 41 & 3.72 & .463 & \multirow{2}{*}{.003} & \multirow{2}{*}{.957} & \multirow{2}{*}{-1.155} & \multirow{2}{*}{.251} \\
\hline & Male & 82 & 3.81 & .431 & & & & \\
\hline \multirow{2}{*}{$\begin{array}{l}\text { Ability to understand and } \\
\text { analyze emotions }\end{array}$} & Female & 41 & 3.82 & .570 & \multirow{2}{*}{1.649} & \multirow{2}{*}{.202} & \multirow{2}{*}{-.502} & \multirow{2}{*}{.617} \\
\hline & Male & 82 & 3.87 & .500 & & & & \\
\hline \multirow{2}{*}{$\begin{array}{l}\text { Ability to evaluate and } \\
\text { express emotions }\end{array}$} & Female & 41 & 3.69 & .502 & \multirow{2}{*}{1.436} & \multirow{2}{*}{.233} & \multirow{2}{*}{.717} & \multirow{2}{*}{.475} \\
\hline & Male & 82 & 3.61 & .591 & & & & \\
\hline \multirow{2}{*}{$\begin{array}{l}\text { Ability to manage } \\
\text { emotions }\end{array}$} & Female & 41 & 3.20 & .588 & \multirow{2}{*}{.022} & \multirow{2}{*}{.883} & \multirow{2}{*}{-1.196} & \multirow{2}{*}{.234} \\
\hline & Male & 82 & 3.34 & .648 & & & & \\
\hline \multirow{2}{*}{ Social support } & Female & 41 & 3.30 & .558 & \multirow{2}{*}{.917} & \multirow{2}{*}{.340} & \multirow{2}{*}{-.035} & \multirow{2}{*}{.972} \\
\hline & Male & 82 & 3.30 & .636 & & & & \\
\hline \multirow{2}{*}{ Problem solving } & Female & 41 & 3.49 & .447 & \multirow{2}{*}{.814} & \multirow{2}{*}{.369} & \multirow{2}{*}{-.188} & \multirow{2}{*}{.851} \\
\hline & Male & 82 & 3.51 & .535 & & & & \\
\hline \multirow{2}{*}{ Emotional discharge } & Female & 41 & 3.47 & .566 & \multirow{2}{*}{.002} & \multirow{2}{*}{.967} & \multirow{2}{*}{-.092} & \multirow{2}{*}{.927} \\
\hline & Male & 82 & 3.48 & .587 & & & & \\
\hline Avoidance & Female & 41 & 3.41 & .446 & 1523 & 220 & -1038 & 301 \\
\hline Rivivane & Male & 82 & 3.51 & .542 & $1.02 \mathrm{~J}$ & .220 & -1.000 & .001 \\
\hline Fmotional Intelliqence & Female & 41 & 3.57 & .394 & 258 & 613 & 468 & 641 \\
\hline 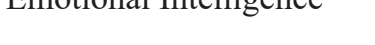 & Male & 82 & 3.61 & .392 & .250 & (0) & -.400 & .041 \\
\hline
\end{tabular}


Comparison of stress coping strategies and emotional intelligence according to gender did not show any statistically significant differences. Analyzing the relationship between emotional intelligence and its components and stress coping strategies, a statistically significant relationship was found between problem solving as a stress coping strategy and the ability to evaluate and express emotions. This relationship, however, is weak and negative $(r=-.2, p<.05)$.

\section{DISCUSION}

The study has only partially confirmed the formulated hypotheses. In particular, no statistically significant differences between the first- and fourth-year students were found in the estimates of emotional intelligence expression. The results of the research conducted by Fariselli, Ghini, and Freedman (2008) showed a very weak, positive and statistically significant relation between age and emotional intelligence $(p<.01)$. This means that more mature individuals usually have higher emotional intelligence. In this research, 450 residents of the United States, ranging in age from 22 to 70 years, took part. Thus, it can be safely assumed that in our research the link between emotional intelligence expression and participants' age was not found due to a small difference in respondent age. The current study involved firstand fourth-year undergraduate students with an age difference of three or four years. In the study by Fariselli et al. (2008), the age difference between the oldest and youngest participants was 48 years, and a very weak relationship between emotional intelligence and age was found. Our assumption about why we failed to discover statistically significant relation between emotional intelligence and age is further supported by the results of the study of Ciarrochi, Chan and Bajgar (2011). This study included 131 adolescents aged from 13 to 15 years. The questionnaire of Schutte et al. (1998) was also selected for the research. Girls were found to have higher levels of emotional intelligence than boys, but there were no statistically significant differences in emotional intelligence ratings between adolescents of different ages.

A similar result was obtained in the study of Harrod and Scheer (2005), which included 200 young people aged from 16 to 19 years. The aim of the study was to determine the relationship between the emotional intelligence level of the participants and their demographic characteristics. The questionnaire by Schutte et al. (1998) was used to assess emotional intelligence. The results of the study showed that there were statistically significant differences in the estimations of emotional intelligence according to gender and educational level of parents. No statistically significant differences were found between the different age groups of the participants.

From the analysis of the above mentioned studies it can be concluded that in all of them there was a difference in the estimations of emotional intelligence according to the gender of the participants: the level of emotional intelligence of female participants was statistically significantly different from that of male participants. It should be noted that in our study, no significant differences were found between the estimations of emotional intelligence according to the gender of participants. The results of our study do not contradict to the findings of Kar, Saha, and Mondal (2014), who aimed to determine the relation of high school students' emotional intelligence according to their gender. The study involved 235 high school students from different provinces of India. Mondal's Emotional Intelligence Inventory (MEII) was used to measure expression of emotional intelligence, and ANOVA was used to analyze the quantitative data. In this research no significant differences were found in the estimates of emotional intelligence according to gender.

The study by Yogun and Miman (2016) aimed to determine the relation between the level of expression of emotional intelligence, demographic parameters (gender, age, education), and workrelated characteristics (experience, position). The sample of the research included 64 participants from Turkey. The level of emotional intelligence was measured on five subscales: self-motivation; self-awareness; social skills; self-regulation; and empathy. Significant differences between male and female participants' ratings were found only on the self-awareness scale. No significant gender differences were found in the generalized indicator of emotional intelligence. Therefore, it can be concluded that not all studies establish a statistically significant relationship between participants' gender and their estimates of emotional intelligence. An overview of the different surveys, their sample, the data collection methods applied, as well as the methods used to analyze the data collected, show that different results are obtained 
in different samples, using different data collection instruments and analysis methods. We believe that the study should be replicated using other tools for measuring emotional intelligence. This would provide a basis for more general conclusions.

Our hypothesis about the relation between stress coping strategies, the gender of the participants, and their year of study was only partially confirmed. No statistically significant differences were found in the respect of participants' gender based preferences for any stress coping strategy. The research of Matud (2004) involved 2,816 participants (1,566 females and 1,250 males), ranging in age from 18 to 65 years. A questionnaire was composed to collect data about the application of four stress coping strategies: emotional, avoidant, rational, and withdrawal. The study revealed that female participants were more likely to use emotional and avoidance coping strategies than males. In the study of Eschenbeck, Kohlmann, and Lohaus (2007), 1990 3rd to 8th grade students took part. The study sample consisted of 1033 girls and 957 boys. The Stress Coping Strategies Questionnaire for Children and Adolescents (SSKJ) was used to collect quantitative data. Stress coping strategies were measured on five subscales: social support; problem solving; avoidance; palliative emotion regulation; and anger-related emotion regulation. Girls were found to use social support and problemsolving strategies more frequently than boys, and boys were found to use avoidance strategies more often than girls.

It should be emphasized that there are studies that have not shown statistically significant differences in the choice of coping strategies according to gender. For example, the study of Brougham, Zail, Mendoza, and Miller (2009) involved 166 high school students. The stress coping questionnaire based on a five-factor COPE methodology was used in data collection. Data analysis revealed that both male and female participants tended to choose emotion-focused strategies, but no statistically significant differences were found in application of one or the other strategy according to gender.

It has been found that more experienced students tended to use strategies of social support, emotional discharge and avoidance. Such tendencies are confirmed by the results of other scholars' research. Frydenberg and Lewis (2000) studied stress coping strategies used by students in grades 7, 9, and 11. Adolescent Coping Scale (ACS) was used to collect data. More mature students (14-16 years) were found to be more likely to use social support and problem-solving strategies than less mature students (12-14 years).

Chan, So, and Fong (2009) conducted a study of undergraduate nursing students. The sample of the study consisted of 205 participants. The Coping Behavior Inventory was used in data collection. The analysis of the quantitative data led to the conclusion that older students tended to use a problem-solving strategy more frequently than younger students. It has also been found that older students, who have no strong religious beliefs and have not experienced teacher-induced stress, are more inclined to choose an avoidance strategy than younger students.

In conclusion, the results of our study on the use of stress coping strategies in different age groups are supported by the findings of other authors. It was found that there was a statistically significant relationship between stress coping strategies and emotional intelligence, that is, a weak positive relationship between such emotional intelligence component as the ability to express and control emotions and problem-solving oriented stress coping strategy.

Por et al. (2011) studied the relationship between emotional intelligence of 130 nursing students and stress coping strategies, perceived well-being, and professional efficiency. The results of the study showed a direct relationship between emotional intelligence and problemsolving stress coping strategy. Pau and colleagues (2004) conducted a qualitative study to determine the level of expression of emotional intelligence among graduate students in dentistry and its relationship to the coping strategies used by the participants. The study involved 10 male and 10 female participants who completed five-year dental studies. The results of the study led to the conclusion that participants with higher levels of emotional intelligence were more likely to use the problem-solving and emotional discharge strategies in coping with stress, whereas participants with lower levels of emotional intelligence were more likely to use the social support strategies. A study in Saklofsk, Austin, Mastor, Beaton, and Osborne (2012) involved 216 students. The aim of the study was to investigate the relations between participants' emotional intelligence dimensions and stress coping strategies, as well as between emotional intelligence levels and participants' study achievement. Relationship between the emotion control dimension and problem-solving 
strategies was identified, as well as the one between the ability to understand and analyze emotions and social support strategies.

In summary, there is a relation between a person's age and their choice of stress management strategy. More mature people prefer problemoriented or social support stress coping strategies. There is also a relationship between emotional intelligence and stress coping strategy, which was manifested as a positive relationship between the ability to understand and analyze emotions and problem-solving focused stress coping strategy.

\section{CONCLUSIONS}

The cmparison of emotional intelligence of the firs-t and the fourth-year students of physical education and sports study programs showed that there were no statistically significant differences. Comparison of stress coping strategies applied by the first- and the fourth-year students of physical education and sports degree programs revealed that the fourth-year students tended to use social support, emotional discharge and avoidance strategies more frequently than the first-year students.

Comparison of stress coping strategies and emotional intelligence according to gender did not show any statistically significant differences.

It was found that there was a statistically significant relationship between stress coping strategies and emotional intelligence, that is, a weak, but significant difference between emotional intelligence components such as the ability to express and manage emotions and problem-solving focused stress coping strategy.

\section{REFERENCES}

Bolevičius, V. (2010). Lietuvos studentu krepšinio lygos krepšininku ir krepšininkiu emocinès inteligencijos ypatumai (Magistro baigiamasis darbas). Kaunas: Lietuvos kūno kultūros akademija.

Brougham, R., Zail, C., Mendoza, C., \& Miller, J. (2009). Stress, sex differences, and coping strategies among college students. Current Psychology, 28(2), 85-97.

Chan, C., So, W., \& Fong, D. (2009). Hong Kong baccalaureate nursing students' stress and their coping strategies in clinical practice. Journal of Professional Nursing, 25(5), 307-313. https://doi.org/10.1016/j. profnurs.2009.01.018

Chaplain, R. (2008). Stress and psychological distress among trainee secondary teachers in England. Educational Psychology, 28(2), 195-209. https://doi. org/10.1080/01443410701491858

Ciarrochi, J., Chan, A., \& Bajgar, J. (2011). Measuring emotional intelligence in adolescents. Personality and Individual Differences, 31(7), 1105-1119.

Connor-Smith, J., \& Flachsbart, C. (2007). Relations between personality and coping: A meta-analysis. Journal of Personality and Social Psychology, 93(6), 1080-1091. https://psycnet.apa.org/doi/10.1037/00223514.93.6.1080

Ekici, S., Sari, I., Soyer, F., \& Colakoglu, T. (2012). Do multiple intelligences predict leadership behaviors of physical education and sport students in Turkey? Energy Education Science and Technology: Part B-Social and Educational Studies, 4(4), 1949-1960.

Eschenbeck, H., Kohlmann, C., \& Lohaus, A. (2007). Gender differences in coping strategies in children and adolescents. Journal of Individual Differences, 28(1), 18-26. https://doi.org/10.1027/1614-0001.28.1.18

Fariselli, L., Ghini, M., \& Freedman, J. (2008). Age and emotional intelligence. Retrieved from https://pdfs.se- manticscholar.org/6692/c93fd5b1 fa5f66cb6212c04cb9ce6fc885d6.pdf

Frydenberg, E., \& Lewis, R. (2000). Teaching coping to adolescents: When and to whom? American Educational Research Journal, 37(3), 727-745. https://doi. org/10.3102\%2F00028312037003727

Gintalas, M. (2013). Jaunučiu ir jauniu futbolininku lyderystès, streso ivveikimo strategiju ir laimejimu tikslu siekimo ypatumai (Magistro baigiamasis darbas). Kaunas: LSU.

Glozah, F. (2013) Effects of academic stress and perceived social support on the psychological wellbeing of adolescents in Ghana. Open Journal of Medical Psychology, 2, 143-150. http://dx.doi.org/10.4236/ ojmp.2013.24022

Grakauskas, Ž., Valickas, G. (2006). Streso įveikos klausimynas: keturių faktorių modelio taikymas. Psichologija, 33, 64-75.

Harrod, N., \& Scheer, S. (2005). An exploration of adolescent emotional intelligence in relation to demographic characteristics. Adolescence, 40(159), 503-511.

Hasnulin, V., Riabichenko, T., Hasnulina,A., Skosyreva, G., \& Patrusheva, Y. (2014). Dependence of cognitive processes from the individual psychophysiological characteristics of upper-school students of a Special Lyceum. Open Journal of Medical Psychology, 3(03), 185-189. http://dx.doi.org/10.4236/ojmp.2014.33020

Jonys, G. (2016). Globos namuose gyvenančiu paaugliu emociniu gebejimu raiška (Magistro baigiamasis darbas). Kaunas: LSU.

Lazarus, R. (2006). Emotions and interpersonal relationships: Toward a person centered conceptualization of emotions and coping. Journal of personality, 74(1), 9-46. https://doi.org/10.1111/j.1467-6494.2005.00368.x 
Kar, D., Saha, B., \& Mondal, B. C. (2014). Measuring emotional intelligence of secondary school students in relation to gender and residence: An empirical study. American Journal of Educational Research, 2(4), 193 196. doi: 10.12691/education-2-4-3

Masten, R., Tušak, M., Zalar, B., \& Ziherl, S. (2009). Stress, coping and social support in three groups of university students. Psychiatria Danubina, 21(1), 41-48.

Matud, M. (2004). Gender differences in stress and coping styles. Personality and Individual Differences, 37(7), 1401-1415. https://doi.org/10.1016/j.paid.2004.01.010

Palmer, B. R. (2003). An analysis of the relationship between various models and measures of emotional intelligence (Doctoral dissertation). Melbourne: Swinburne University of Technology.

Pau, A., Croucher, R., Sohanpal, R., Muirhead, V., \& Seymour, K. (2004). Emotional intelligence and stress coping in dental undergraduates - a qualitative study. British Dental Journal, 197(4), 205-217.

Por, J., Barriball, L., Fitzpatrick, J., \& Roberts, J. (2011). Emotional intelligence: Its relationship to stress, coping, well-being and professional performance in nursing students. Nurse Education Today, 31(8), 855-860. https://doi.org/10.1016/j.nedt.2010.12.023
Postek, S., Ledzińska, M., \& Czarkowski, J. (2010). Psychological and pedagogical problems of distance education for adults. Problems of Education in the 21st Century, 22, 1-10.

Saklofske, D., Austin, E., Mastoras, S., Beaton, L., \& Osborne, S. (2012). Relationships of personality, affect, emotional intelligence and coping with student stress and academic success: Different patterns of association for stress and success. Learning and Individual Differences, 22(2), 251-257. https://doi.org/10.1016/j. lindif.2011.02.010

Schutte, N. S., Malouff, J. M., Hall, L. E., Haggerty, D. J., Cooper, J. T., Golden, C. J., \& Dornheim, L. (1998). Development and validation of a measure of emotional intelligence. Personality and Individual Differences, 25, 167-177. https://doi.org/10.1016/S0191-8869(98) 00001-4

Šmitas, A., Perminas, A. (2015). Studentų D tipo asmenybejs ir jos komponentu sąsajos su sveikatai nepalankiu elgesiu. Visuomenés sveikata, 3(70), 68-74.

Yogun, E., \& Miman, M. (2016). Impact of the demographic factors on the emotional intelligence level: A research of the food and beverage sector. International Journal of Business and Management Invention, 5(2), $17-25$. 